\title{
THE PROTO-DIPLOMATIC DOCUMENT IN ROMANIA
}

\author{
Adrian Petre POPESCU \\ „Lucian Blaga” University of Sibiu, Romania \\ popescusibiu@yahoo.com
}

\begin{abstract}
The theme is decoding the "literary field of the Romanian proto-diplomatic document", designed to replace the art of diplomacy and cultural regeneration. It is the observation field over the products of literature's habitat, the "art of the word". Therefore, to confirm the "Romanian tradition", we have analysed several of the "literary works" of some Romanian writers from the $19^{\text {th }}$ Century. Under these circumstances, attention is drawn on the role of the document/deed, on its importance in the universe of cultures. Attention is drawn on the occurrence of proto-religious documents and of the proto-diplomatic documents. During the evolution of scripts in the mid $17^{\text {th }}$ Century - presented by Nicolae Iorga as "abandonment of the Franciscan spirit, a change of the entire meaning of the religious literature", we have included in the study the role of Slavic monks (refugees from Mount Athos on our lands) and their apprenticeship in the atmosphere of "mysticism and culture", the impact caused by founders of monasteries, turned genuine centres of culture. Within these monastic places, the art of calligraphy and miniature develops, revived under Matei Basarab, Vasile Lupu and especially during the reign of Constantin Brâncoveanu.
\end{abstract}

\section{Keywords: proto-diplomatic, evolution, document, mysticism, culture.}

\section{Introduction}

The concern with the preservation of texts has grown into a constant feature of Romanian culture. From narrow definitions of the concept, the word "text" has evolved towards a broader meaning. Roger Chartier's opinion is expressed in similar terms: "The changes of our time simultaneously upset the foundation of writing, the techniques of its reproduction, dissemination and how it is read. Such simultaneity is unprecedented in the history of humanity". Through its importance and addressability, our thematic proposal can be undertaken by various forms of scientific analysis. Even if the texts of authors selected for this study are dominated by the exposure of historical facts, we find a concern for expressiveness, originality and a gradual evolution of writing. Literature of the "feudal era", established with the attempt to assert writing in Romanian, bringing to the general attention - despite borders between provinces - themes, motives, ideas, actions to preserve the national unity. In this regard, Adrian Marino confirms that literature does not ever develop into a cultural, social and ideological vacuum"[1]. In the area of interest of pre-diplomacy we have also integrated the genetic path between communication and development which is reserved for decoding the "literary field of the Romanian proto-diplomatic document", designed to replace the art of diplomacy and cultural regeneration. It is the observation field over the products of the literature's habitat, the "art of the word". Despite some communication difficulties, Romanian medieval scribes have proven that they have patiently educated followers and readers managed to translate the word discreetly, faithfully and unostentatious. 


\section{The habitat of proto-diplomatic literature}

We start from the assumption that there might be a mutual determination and interdependence between the cultural "product" and its "producer", in an indirect manner, by means of the cultural reality of the world of Symbolism. Roman Osipovich Jakobson defined six functions of language (or communication functions), according to which an effective act of verbal communication can be described [2]. Each of the functions has an associated factor. When we want to research the past we can not talk about it if we have no visual or written information about the proposed subject [3]. Umberto Eco believes that such research is the result of selective memorizing [4]. It works not only on the individual level, but also on the social level. Thus, through a combination of the author's own reading and writing experiences, presented and perceived intertextually and intratextually throughout the text itself, and a series of fictionalized versions of personal experiences, not only is the reader able to gain insight into the author's motives, intentions and personality, but the author is also able to retain or regain some of the authority over the text he or she creates. Following the "neutralization" of the other features of the text, it should be indifferent to the distinction between the literary and the non-literary text. Marielle Abrioux advanced the hypothesis that the nonliterary verbal storytelling study is based, for the most part, on the results of the study of literary narrative, precisely because on the level at which these analyses are made, they can not take into account a hypothetical definition of literalness" [5]. According to Umberto Eco "perfect language history would begin with the Bible": Torah scrolls that are Kabbalistic works is only a starting point. One of the Kabbalistic tradition versions to identify the meaning behind the sacred text [6] Rabbi Moses Gaster, is a pioneer of daring to attempt to systematize more than 200 manuscripts from the $16^{\text {th }}$ Century and the $18^{\text {th }}$ Century. "The chrestomathy" indicates such a manuscript of a priestly hand [7]. Among the sources used by the Rabbi, we encounter calligraphy and miniaturism texts of the sixteenth Century and the eighteenth Century [8]. Even if they show some difficulties in grammatical expression and communication, we can say about Romanian medieval writers that they show to the readers the written world and also the Romanian world.

\section{The medieval cultural environment}

From the perspective of those who admire the medieval environment, the cultural influences in Romania appear as under the influence of cultural and diplomatic channels of Byzantine, Italian and Slavic cultural-religious ways of diplomacy but also the militaryadministrative ways. Under these circumstances, attention is drawn to the role of documents/deeds, on their importance in the universe of cultures. Attention is drawn to the occurrence of proto-religious documents and of the proto-diplomatic documents. During the evolution of scripts in the mid seventeenth Century - presented by Nicolae Iorga as "abandonment of the Franciscan spirit, a change of the entire meaning of the religious literature" [9], we have included in the study the role of Slavic monks (refugees from Mount Athos on our lands) and their apprenticeship in the atmosphere of "mysticism and culture" [10]; the impact caused by the founders of monasteries, turned genuine centres of culture. Such writings became the subject of research for Hans-Georg Gadamer [11], Northrop Frye (we exemplify with volumes: "Anatomy of Criticism", "The Critical Path", "The Great Code"), Paul Ricoeur (author who wrote: "Le conflit des interpretations", "L'ideology et l'utopia", „Penser la Bible”) or Walter Ong ("The Presence of the Word"). They have concluded that we can justly talk about a certain continuity and contiguity in the cultural phenomenon. Within these monastic places, in the actual territory of 
Romania, the art of calligraphy and miniaturism develops, revived under Matei Basarab, Vasile Lupu and especially during the reign of Constantin Brâncoveanu. In this respect, reports of writers and copyists are surprisingly offering a diverse perspective, such as Culturology, which is important in the process of writing, reception and decoding sequences and in the aesthetic life. Through this process, we evaluate literary works of a writer and his popularity [12].

\section{Neagoe Basarab's writings}

We have noticed that some protodiplomatic scrolls record relations between local leaders and the "outside" of the Court. One such example is the diplomatic correspondence between Pope John XXIII (1327) and the one called "Voievod Transalpinus Bazaras" (alias: Basarab), who calls for protection and security for the pontiff and his Dominican monks. The document highlights the complexity of international relations that have lifted Romanians through Basarab I, in regard to the people of Central and Eastern Europe [13]. The content of such reports and correspondence or dispatches during protodiplomacy, to which we refer, heralded the need to build institutions capable of managing cultural, diplomatic, military, etc. relations between "issuers" and those of public institutions. Such a formula of literarity, as a deviation from the common standard speech which triggers emotional and esthetical effects to the reader is also encountered in Neagoe Basarab's writings. "Cuvântul dintâiu al Învăţăturilor"/"The first word of the Teachings" [14] encourages us to approve the views according to a pseudo-discourse focused on outlining the destiny of a "King of character", characteristic to the "princely man", able to take on the bright life as a heavenly, Divine gift. A part of the world's visible and invisible mysteries, "the bitter secrets" of life, the "challenges" that history will make the "princely man" face Theodosie the apprentice - will be revealed gradually to him, through an idiolect characteristic to the popular literature: the Christian novel "Varlaam si Ioasaf", the homilies of John Chrysostom, Ephrem the Syrian, and so on. Neagoe Basarab, as Great Counselor / Grand Master is in front of a novice, towards whom he connected/attached, especially spiritually. Our supposition is strengthened by other factors, such as the "clothing" of the prince, presented in frescoes, which appear on a red brocade robe with a golden two-headed eagle (like the Egyptian eagle, taken later as the Egregor / symbol for the Freemasons, with references to God or Sun, God Mendes) and an imperial crown. In fact [dé fakto], we are in front of an allegorical exegesis [15]. The teachings of the Grand Master provide an esoteric way of mediated instruction - through legends and symbols, that is why the "Teachings" may be considered as a Doctrine and ethical manual for caste, with advices and encouragements for difficult moments, all combined with talent and obvious literary skilful writing. Coincidentally dominated by pages of examples, stories and characters (taken from the Old Testament), we can say that the "Teachings" are, above all, "The Great Confession, fundamental utterance about the truths of life, which feels the breath of extinction". "The teachings of Neagoe" have a similar content, sources left by Herodotus, those relating to the cult of Zalmolxis, who, under the influence of sage Pythagoras, builds a "meeting house for men", where, after three years of solitude, entrusts his teachings to the people [16]. In our opinion, the meaning of this document refers rather to the "possible resources of the common language", with the stipulation taken from Gerard Genette, namely to notice the expressive function of the "Teachings" language because, as it is wisely mentioned by the same Genette, the resources of the language are invested only in a "discourse", oral or written, literary or not. Taking note of Genette, the study focuses on the "informal literarity" of some old "texts" [17]. Two directions can be 
distinguished from the study: the first one considers literarity as inherent and the second direction designed to explain the situations in which a text may become, or ceases to be a creation. Another direction in approaching the general topic is proposed in "Contours of the Romanian medieval literarity established in the works of certain representative Freemasons diplomat writers".

\section{The Spatharios Nicolae Milescu}

Milescu is one of the special envoys who have received diplomatic powers to establish relationships with people of culture from Europe [18]. Such knowledge and diplomatic skills demonstrated by "scholar Milescu" are exemplified in a manuscript found in the secret library of a lodge in Focsani. It becomes a testimony on the Spatharios' training back in Italy (Padova), as resulting from the content of the book "The twelve Sibyls, about numbers and their prophecies" [19]. Milescu takes us to the "herald of mysteries" (Rosenkreutz), just like in the Vergil's eclogue/pastoral. In the cultural emancipation note, George Călinescu appreciated the translation of the "Bible" by Milescu, considering that its printing would be for Romanians what Luther's Bible is for Germans. Milescu translated "The Scripture" to unite believers, to avoid the dying out of the belief and to provide literates with the possibility to always meditate on the divine message [20]. And for that reason Milescu is considered by his contemporaries "vir poliglotus et perdoctus", considered as a genuine predecessor of cultural diplomacy. Furthermore, Milescu's spiritual, social and cultural activity shows that the Rosicrucian myth, that of the Rosicrucian Fellowship, was neither a simple literary exercise, nor a formal diplomatic approach. The letters, but also the friendships of Spatharios Milescu carry on under the sign of the Rose and express the pan-European Brotherhood "which wanted to light up the sixth Candelabrium", < the great sixth Age > (specific to Rosicrucian manifestos). This idea of a "literature of innovators" is a leitmotif encountered in Milescu's writings, according to which we understand why he gives special attention to Asian schools of thought and to the Latin-Orthodox current that permeated, splitting up the Russian world. Milescu's predisposition to the occult, the desire to decipher the great mysteries and to get acquainted to the secrets of Christian Kabbalah, once more sets him closer to the spirit of the "philosophy of Hermes", that Gnostic mysticism practiced by all Rosicrucians, either Western or Eastern. Milescu wrote HIS Latin the work "Stella Orientalis Western sive Enhiridion splendens, sensus Ecclesiae Orientalis id est, scilicet Graeca of transsubstantione Corporis Domini, allisque controversiae" (printed in Paris in 1669 under the title "Eglise catholique La perpetuity touch l'Eucharistie"). It was the second LITERARY WORK of a Romanian to appear in Western Europe after the "confession" of Petru Movilă [21]. Milescu's predisposition toward occultism is noticed by Radu Cernătescu when referring for example to the "book about hieroglyphs" (released in 1675). Milescu approaches once more the spirit of "the philosophy of Hermes", that gnostic mysticism practiced by all Rosicrucians, be they Western or Eastern [...] in such a manner that Englishman John Webster, requested the "Academiarum Exam" (1654) for him to become a subject of study in English Universities, probably following the example of the "Accademia dei Segreti". From the Freemason profile of the humanist "Nicolo SpadarioMolodovalaccone (sic), barone ac olim generali Wallachiae", we cannot overlook the theological arithmology discourse, based on a decryption of the symbolistics of numbers (Creation/which governs the manifestation; Organisation/which governs the phenomena in the Universe; Birth/which governs Time, the moment of conception) or the translation of prophecies about the fate of the four monarchs who 
would rule the world, "Daniel's prophecies", followed by the transposition of the prophecies of Sybil [22]. Going through the creation of Spatharios Milescu we discover the new spiritual configuration of the Romanian culture, a signal given by new erudite scholar kings.

\section{5. „Senior” Ienăchiţă Văcărescu}

"Counsellor of the princedom", he is also a "character" from the "list" of the Romanian cultural pre-diplomacy, initiated in the art of Eastern and Western "ceremony" [23]. Ienăchiţă Văcărescu, the guest of honour of Emperor Joseph II of Austria, Great-Treasurer during the reign of Grigore Ghica, Spatharios during the reign of Ipsilanti, High Steward under the Mavrogheni and again treasurer under Nicolae Caragea, he enjoys all the privileges of the Western and Eastern culture also due to his distinguished education. Ienăchiţă Văcărescu's creation is subtlety underlined by George Călinescu with a synthetic "stroke of the pen": "a much more educated man" than his contemporaries, "a true intellectual", a personality that expresses the landmarks of "enlightened absolutism" from Prussia of Frederic II, Russia of Catherine II or Austria of Joseph II, co-regent of his mother, Maria Theresa. The fact that the literature written by him has, besides the well-known popular echo, a rich esoteric arsenal, discreetly placed in his short poems, can be decrypted only in this context of approximating the limitations and reviewing the "specific distance" between border and centres (Vienna and Constantinople). His knowledge and manners captivates the Emperor of Austria, who will show great appreciation, like the one he had for Samuel Brukenthal, Governor of Transylvania, who Iancu Văcărescu will meet in Sibiu (1781) during the return mission to the country of Alexandru Ipsilanti's sons. It was not the first meeting with Emperor Joseph II and with those from the Brothers of the Cross Lodge. The first contact, according to the data recorded in the volume "Treasury of historical monuments for Romania", would have taken place during the riot years of 1770. Under the same "diplomatic ability", Ienăchiţă Văcărescu, this time as a "delegate" to the Russian-Turkish peace Congress in Focsani (1722), manages to get a "free pass" from the Field Marshal Piotr Aleksandrovici Rumeanţev [24]. His fictional and factual writings allow us to reconstruct his personality as man of culture, polyglot, historian, philologist, as revealed in "Turkish history" (the second history of the Turkish Empire written by a Romanian, after that written by Cantemir), for which Văcărescu uses origins from Turkish books, byzantine chronicles, German and French books, without overlooking Cantemir's writings. The other works bear the imprint of the contact with Romaic literature, Anacreontic poetry, French and Italian novel writings. For the achievement of the portrait of this Romanian polyglot, the efforts of Iancu Văcărescu to write several dictionaries/glossaries (Romanian-German, German-Romanian, Romanian-Turkish, Turkish-Romanian) should also be mentioned [25]. It is the portrait of a "comrade of enlightenment of the Romanian people" as resulting from his philosophical, historical writings but also from his poems. An adept of enlightenment, a promoter of the burst of the Romanian language and culture, Văcărescu meets with all finders of the truth at the turn of the 18th Centuries and 19th Centuries, leading the way towards the new flow, by an educated sentimentalism, sometimes touched by the romantic "dream" and "irony", but not yet faithful enough to the philosophy of lights and "innovation through culture".

\section{Conclusion:}

This article intends to demonstrate the objectives of cultural diplomacy used by the Romanian literates-diplomats on the political and cultural map of Europe. We insist on exploring semiotic argumentations around the ,primary phenomenon" of a 
nation, the whole structures that define a group, a community or a society, and separates them one from the other. The reflection was redirected in a historic setting of national and international diplomacy on pre- and proto-diplomacy, accepted as a canonical basic element of diplomacy at the end of the $18^{\text {th }}$ Century.

\section{References}

[1] Marino, Adrian,'National literature", in: The ideas biography of literature, vol. V, ClujNapoca: Editura Dacia: 1998.

[2] Waugh, R. Linda, "The Poetic Function in the Theory of Roman Jakobson", in: Poetics Today, Marks, Signs, Poems: Semiotics, Linguistics, Poetics, Toronto: Semiotic Circle: 1982.

[3] Ibidem

[4] Eco, Umberto, Vegetable Memory, Bucureşti: RAO: 2008.

[5] Ducrot, Oswald and Schaeffer, J. Marie, Nouveau dictionaire encyclopedique des sciences du langage, Paris: Editions du Seuil: 1995.

[6] Eco, Umberto, In search of perfect language, Iaşi: Polirom, Print: 2002.

[7] Gaster, Mozes, Romanian chrestomathy, vol. I, București: Socecu \& Co: 1891.

[8] Stanciu, Măriuca, The unknown Gaster, București: Editura Universităţii București: 2006.

[9] Iorga, Nicolae, Romanian literature history. București: Minerva, Print: 1985.

[10] Cartojan, Nicolae, The old Romanian literature history, București: Minerva: 1980.

[11] Hans-Georg Gadamer, Wahrheit und Methode,Tübingen: 1960,

[12] Manolescu, Nicolae, Literary chronicle role, Braşov: AULA: 2001.

[13] Cartojan, Nicolae, The old Romanian literature history, București: Minerva: 1980.

[14] Djuvara, Neagu, A brief history of Romanians told to the young, Bucuresti: Humanitas: 2008.

[15] Buffière, Félix, Les Mythes d'Homère et la pensée grecque, Paris:Les Belles Lettres: 1956.

[16] Popescu, Adrian Petre, Romanias writers, diplomats and freemasons in $19^{\text {th }}$ century, Sibiu: ASTRA Museum: 2013.

[17] Genette, Gerard, Fiction et diction, Paris: Éditions du Seuil: 1991.

[18] Berindei, Dan, From the beginnings of modern Romanian diplomacy, Bucureşti: Editura Politică: 1965.

[19] Cernătescu, Radu, The Lucifer literature. An occult history of Romanian literature, București: Cartea Românească: 2010.

[20] Cartojan, Nicolae, The old Romanian literature history, București: Minerva: 1980.

[21] Popescu, Adrian Petre, Romanias writers, diplomats and freemasons in 19th century, Sibiu: ASTRA Museum: 2013.

[22] Cernătescu, Radu, The Lucifer literature. An occult history of Romanian literature, Bucureşti: Cartea Românească: 2010.

[23] Author Călinescu, George, Romanian Literature history, Compedium after A1.Piru, București, Publishing House for Literature: 1968.

[24] Cândea, V. et al., Pages of the past Romanian diplomacy, Bucureşti: Editura Politică: 1966.

[25] Nestorescu, Andrei et a., Ienăchiţă Văcărescu's dictionaries and literary Romanian language in the late eighteenth century, București: Institutul de Lingvistică al Academiei R.S.R.: 1969. 